\title{
Canadian Disability Activism and Political Ideas: In and Between Neo-Liberalism and Social Liberalism
}

\author{
Michael J. Prince, Ph.D., University of Victoria \\ MPrince@uvic.ca
}

\begin{abstract}
The Canadian disability movement expresses a style of activism distinguished by values and beliefs which are a form of social liberalism. Disability activism, however, is taking place within a contemporary setting in which a set of ideas and interests often called neoliberalism prevail in political discourse and policy making. This article considers the role of neo-liberalism and its interplay with social liberalism in relation to the full citizenship goals of the Canadian disability movement. Political activism, among other things, is a discursive production; an expression of ideas and information as well as a performance of power. Disability activism, in the Canadian context, is a form of social liberalism that emphasizes individual self-development and also community and the rights of numerous politically salient social groups. In many respects, social liberalism is a counter-discourse to the dominant discourse of neo-liberalism; in other ways, they are mutually reinforcing systems of ideas; and, at all times, they connect together in a larger historical and institutional context of particular societies.
\end{abstract}

\section{Keywords}

Disability; Neo-Liberalism; Social Liberalism; New Social Movements; Canada 


\section{Canadian Disability Activism and Political Ideas: In and Between Neo-Liberalism and Social Liberalism}

\section{Introduction}

What kinds of politics do people with disabilities and organizations of the disability community practice? What are the implications for citizenship of neo-liberalism? This article goes beyond the widely analyzed and well accepted argument of the ascendancy of neo-liberal ideas in governing practices and social policies in Canada and around the world. Indeed, some claim the absolute and ubiquitous triumph of neo-liberalism:

Neo-liberalism is perhaps the most pervasive social system to ever have existed in the history of the world. That is true in two senses. First and most obviously, it is geographically pervasive, to a greater and lesser extent the dominant system in almost the entire world .... Neo-liberalism is pervasive in another less discussed, but perhaps even more significant way. Within the societies in which it is most dominant, neo-liberalism has penetrated into every corner of the society, shaping all major institutions, ways of thinking, and human interactions. The logic of the market and competition and short-term thinking are everywhere. (Clawson 2008: 207)

My main focus is on how the objectives of progressive interest groups and social movements relate to, differ from, and interact with neo-liberalism. The purpose of this article is to situate neo-liberal ideas and other political ideas within a specific political 
setting and societal context of discourses on policy. As a qualitative and critical inquiry, the following discussion draws upon a review of the literature on disability studies and the welfare state in Canada as well as the author's observations through participation with a number of disability organizations, at the national and provincial level, over the past 15 years. Through personal observations of events, informal interviews, group discussions and analysis of documents, I have put together this interpretive understanding of the collective goals, working assumptions, and points of view of the Canadian disability movement. The analysis shows how the disability movement in Canada constitutes a particular representation of "the social" (Clarke 2007; Higgins and Lockie 2002; Prince 2001).

In addition to the apparently dominant discourse of neo-liberalism, Canada is a society in which other political discourses are in play, most notably Québec nationalism, the self-determination agenda of indigenous peoples, feminism, and multiculturalism. These diverse mixtures of discourses and belief systems have prominence in the political culture and mass media, and help shape the nature and impact of neo-liberalism. All of this contributes to a Canadian perspective on disability issues and disability studies.

Moreover, in contemporary politics, liberalism is a heterogeneous set of ideas, values and preferred reforms (Delanty 2000; Dwyer 2004). In some respects, social liberalism as a set of political beliefs closely relates to neo-liberalism on the ideological spectrum of possibilities, while in other respects social liberalism is importantly different in expression through political activism and policy advocacy. In this article, I describe the 
national style of disability activism, suggesting that ideologically the characteristic Canadian approach is a form of social liberalism, while comparing it to the ever-present discourse of neo-liberalism. ${ }^{1}$

Canadian disability movement politics share features with the movements in Australia, Britain and the United States, among other countries. Self-organization as a feature of new social movements is a notable characteristic of the disability community today, illustrated with the rise of the independent living movement since the 1970 s and represented by Independent Living Canada. Like other social groups and disability movements in other countries, the Canadian community emphasizes post-materialist values of cultural meaning. Anspach (1979) describes this activism among disabled people as a shift from stigma to identity politics. Anspach uses the term "identity politics" in reference to altering self- and societal-conceptions of people with disabilities from passive, deviant, and powerless to positive, self created conceptions for themselves. He also distinguishes the mode of movement organizations from other arenas in the community. In contrast to service organizations, such as charitable agencies and self-help groups, disability movement organizations are political in outlook not therapeutic, of the disabled rather than for the disabled, and adopt a more polemical tone in their activities. "Identity politics," states Anspach, "is a sort of phenomenological warfare, a struggle over the social meanings attached to attributes rather than an attempt to assimilate these attributes to the dominant meaning structure" (1979: 773). 
Struggles of the disability movement are not to the exclusion of material issues of employment, accessible education, and income security or to the exclusion of governmental issues of public participation in policy making. A politics of socioeconomic redistribution is at the core of disability activism in Canada, complemented by a politics of recognition and a democratic politics of representation, the latter of which involves claims for more accessible, empowering, and accountable policy making structures and processes (Prince 2009). This view of Canadian disability politics departs then from the notion that new social movements focus exclusively or even chiefly on identity and post-materialist values. Active in claiming a self-defined identity in place of that previously dominant in society, disability movement organizations question traditional state practices and professional controls. Challenging a purely bio-medical perspective on disability, activists are promoting a socio-political model with a focus on the interaction between individuals and the larger environment. The psychiatric survivors' movement calls for drug-free treatments and greater use of peer counselling, while the 'mad movement' is promoting dignity and self-respect around bipolar disorder and schizophrenia. These movements, which overlap in some ways, convey strong interest in social reform and in public services and programs generally (Burstow and Weitz 1988; Capponi 1992; Shimrat 1997).

\section{Neo-liberalism in Practice}

A notable feature on the Canadian political landscape is the presence of and interplays between the dominant discourse of neo-liberalism and an alternative discourse of social 
liberalism, variants of both of which are expressed by different interests, groups and social movements (Little and Marks 2006; McBride and McNutt 2007; Orsini and Smith 2007; Prince 2001).

While multiple frames of citizenship vie for attention, neo-liberalism as the preeminent political frame in our present age certainly conditions which approaches to citizenship are encouraged and which discouraged by governments and other institutions. In a study on home care in Ontario, for example, Aronson and Neysmith conclude that the marginalization of the elderly and persons with disabilities, "is deepened by neoliberal conceptions of citizenship that prize self-sufficiency and independence, disparage need and dependence and, thus, permit receding state intervention and greater privatization of care" (Aronson and Neysmith 2001: 153). With privatization and contracting-out of formerly public services, comes 'a consumerist, market-oriented conception of citizenship rights in which the citizen is transformed into a customer' (Lister 1997: 206). Neo-liberalism promotes additional troubling notions of citizenship. The personal tragedy, charitable, and medical-oriented notions of citizenship converts Canadians with disabilities, respectively, into citizens with spoiled identities, as supplicants and as sick patients.

Canadian towns and cities, as elsewhere, are places of exclusion for many women, ethnic minorities, sexual minorities, indigenous peoples, and persons with mental health conditions and physical disabilities. In this context, persons with disabilities remain largely defined and governed by bio-medical and personal tragedy models, 
despite the rise of rights-talk. In the past twenty years, some positive changes have occurred, yet the world of policy and practice remains decidedly categorical, regulatory, and stigmatizing for Canadians with disabilities. Cultural practices based in notions of order, health, and normality still include tendencies of "othering" people: to confine, invalidate, exclude, and fix individuals and groups of people seen as having differences and deficiencies. A main reason for this discouraging state of affairs is the negative impacts of neo-liberalism as revealed in welfare state rollbacks, social program cuts, and the offloading of responsibilities for public provision onto communities, private firms, voluntary agencies, and families (Lorinc 2006).

Encouraging market solutions is of course a central principle and technique of neo-liberalism (Myles 1998; Prentice 2004). It involves giving room for private sector measures in health and social policy, and often promoting the market economy, through incentives, to supply more adequate benefits or services to those able to afford such measures. Closely related is the process of governments privatizing, commercializing, and divesting themselves of clients and services. Privatization measures in Canadian social services have included such measures as canceling the provision of non-statutory services; reducing the provision of some statutory services through bureaucratic disentitlement, a process of modifying internal practices that exclude certain clients or increase barriers to obtaining services; contracting existing and new services to nonprofits and for-profit organizations; transferring services to other jurisdictions; increasing user fees for services; and, reframing the nature of social problems so that their causes and or solutions seemingly lie outside government responsibility. 
Reproducing existing status differences among people also occurs in income maintenance programs among people as a result of basing the value of benefits on earnings-related contributions, which is a standard feature of social insurance programs. It also occurs through the use of fees and charges to finance the delivery of programs and the use of tax credits, deductions, and exemptions to deliver benefits. Another bundle of technologies reflects the impact of neo-liberalism on present age policies and practices. One of these concerns devolving public responsibility - locating accountability for policy design and program delivery to lower levels of government (at times called offloading or downloading), and therefore guaranteeing differences in scope, accessibility, adequacy, and quality of like programs across jurisdictions in the country. Another involves individualizing and objectifying people as cases - treating the needs and circumstances of people narrowly by ignoring applicants' and recipients' full social and economic location (age, ancestry, gender, language skills, educational qualifications, family status, strength of the local economy, and so on), and translating their life experiences and circumstances into administrative terms and program imperatives.

These measures do not exhaust the possibilities, but the point is that groups already marginalized in society, people experience these techniques as exercises of disciplinary power, whether in the form of initial ineligibility, subsequent disentitlement, increased regulations, enhanced surveillance and enforcement measures, or in the physical design of social service offices. This is a gloomy and pessimistic outlook of the state's potential to achieve many of the social security and equity goals conventionally 
attributed to the welfare state, including full citizenship. This perspective is in reaction to what many saw as a golden age of progressive intervention, with governments of late, under the influence of neo-liberalism, retreating from those commitments (Guest 2003). The result, in the dramatic language of one policy analyst, is akin to "waging war on the welfare state" (Campeau 2004). "The direction of social policy in Canada over the past decade," observe Schaefer and Smith (2005: 225), "has been toward a leaner, more restrictive access to government subsidies for the poor" as well as for the unemployed; categories which include disproportionate numbers of the disabled.

With the privatization of certain state care programs, persons with disabilities "are not seen as worthy of investment for future return" in market terms of profit margins (McDaniel 2002: 143). As social policy reform stalled or stopped altogether, the welfare state has shrunk, accompanied by a disturbing trend toward what McDaniel calls the criminalization for not caring: "Individual responsibility is stressed, with structural inequalities either not seen or denied. A struggling lone mother, for example, caring for a disabled child with dwindling supports from the state, may be charged with neglect despite the reality that she may be doing all she possibly can with limited or no supports" (2002: 144).

Certainly, government restraint and downsizing in social affairs is one of the critical factors that severely limit the influence of advocacy initiatives. Another widely noted factor is economic globalization and restructuring in support of enhanced productivity and market competitiveness. Coupled with these factors is the "new public 
management" ethos, introduced in the bureaucracies of many countries, that privileges efficiency and private sector values over equity and social justice. Each of these factors represents important aspects of neo-liberalism. Two additional factors reflect classical features of complex organizations and bureaucratic behaviour. One of these further constraining factors is the intrinsic tension between the reformist aims of disability groups, and established procedures of government executives and bureaucracies. Moreover, public service structures rooted in vertical portfolios of program activities and ministerial accountabilities consequently often frustrate the ability to promote an integrated and horizontal cross-departmental approach to policy innovations.

\section{Disability Activism as Social Liberalism}

The disability movement in Canada with its associated discourse, political strategies, and policy agenda exhibits a characteristic style, as do the movements in other countries such as Australia, Britain, and the United States (Cameron and Valentine 2001; Chivers 2008; Stienstra and Wight-Felske 2003). The distinctive approach of Canadian disability activism reflects the dominance of liberal values in Canadian society and political culture. Contributing to this style is the unique configuration of federalism, cabinetfocused parliamentary government, the Charter of Rights and Freedoms, and an increasingly multicultural society and urban nation. Located well within a liberaldemocratic tradition, the prominent philosophy in disability activism is social liberalism (O’Connor, Orloff and Shaver 1999; Prentice 2004; Prince 2009). Other terms for this 
form of ideology are developmental individualism, egalitarian liberalism, modified individualism, and progressive or welfare liberalism.

This social liberalism embraces a number of beliefs about the economy, the nature of people, society, the state and the necessity for change and political action. On the economy, social liberalism accepts the existence and fundamental necessity of the capitalist economy and private market relations. The disability movement strives for greater participation of individuals with the full array of physical and mental impairments to participate in the mainstream labour market. The Canadian disability movement is not an anti-capitalist movement or is it anti-globalization. Disability organizations believe significant changes for people with disabilities can happen within existing economic structures. A core element of the struggle for 'access' means access to paid labour. The economic dimension of full citizenship typically assumes gainful employment, rather than the alternatives of shelter workshops or voluntary service masquerading as competitive and fair wage-based work. Disability activists recognize the importance of work incentives in social policy and condemn the work disincentives embedded in various income programs and public services. Moreover, the goal of community living rather than a segregated institutionalized existence also takes for granted the value of personal and private property.

Acceptance of the market economy is not unequivocal. Disability groups call for actions to shift workplace attitudes and practices about abilities; as well, they call for affirmative measures such as employment equity and reasonable accommodations to 
modify market values and forces. At the heart of liberalism is the primacy of the individual and enabling each person to develop and use their capacities to the fullest possible (Macpherson 1977). That every individual has innate capacities, dignity, and equal moral worth is a core belief that strongly resonates with contemporary disability movements. Liberalism with a social outlook relates to rights-based advocacy for equal treatment under the law. It also fits with social and environmental models of disability which, in essence, reject the atomized nature of humanity found in some expressions of rugged individualism, and in the personal tragedy and bio-medical models of impairment.

Hutchison and her associates (2007) distinguish between service agencies with a traditional approach that emphasizes "client hood" and "victim hood" among families and individuals living with disabilities, and a new approach which promotes personal choice and self-determination. It is the latter approach, which is the emerging pathway to social inclusion, especially by "user-led" and "consumer-driven" or controlled organizations, such as independent living resource centres, that has arisen in the nonprofit sector since the 1970s (Hutchison et al. 2007). Here is an instance of social liberalism - the idea that as consumer of services, people with disabilities ought to have the right to decide which service to access, a right to monitor the quality of service provision, and ultimately a right to change services if they so decide. Examples of national consumer-driven disability organizations controlled mainly by people with disabilities, are the Alliance for Equality of Blind Canadians, Council of Canadians with Disabilities, People First of Canada, National Network on Mental Health, and the Canadian Association of Independent Living Centres. 
As an expression of social liberalism, disability activism in Canada places the individual within a larger societal context. Disability activists push hard against longstanding views of disability as a personal problem and private issue (Michalko 2002). Alongside individuals, core elements of society are families, local communities, and other groupings. Disability groups often focus on individuals and their needs, but the general emphasis is not individualistic; individuals are interdependent and interconnected through myriad networks of roles, structures, and relationships, some of which are enabling, and many others, over the life-course, disabling. Over the course of our lives, we are all human, unique, and limited in known and unpredictable ways. Human society has a moral value and material benefit linked with the status and practice of citizenship. Disability groups recognize that the possibility of people realizing their actual capacities relies in large measure on their membership, participation, and sense of belonging in a political society. Rights are for individuals as well as for groups. To advance substantive access and equality, it is necessary at times to treat people identically and at times to treat people differently. The disability movement asserts equality and equity, and individual and group rights as important values of justice.

A notable feature of Canadian disability politics is the state-oriented approach taken by most groups whether for services, agency funding, legislative reforms, policy consultations, or equality claims through litigation (McColl and Jongbloed 2006; Pothier and Devlin 2006). Reasons for a state-focus by disability activists are obvious. Many government programs related to disability have operated for many decades, some with 
profoundly harmful effects for which groups are seeking restitution of various kinds. In more than one jurisdiction across the country, former residents of provincial institutions are seeking and, in some cases, receiving, formal apologies and or financial compensation from government for the physical, psychological or sexual abuse, misconduct or injury they suffered while in care (BCCPD 2011).

Activists point out that the state has never been neutral regarding issues of disability, ability, normalcy, and deservingness. Other new social movements and longstanding interest groups in Canadian politics focus on the state, with varying degrees of success. Because of discrimination and disadvantages, people with disabilities as a group are more reliant on state services than people without disabilities. Instead of some mythical notion of neutrality, disability advocates argue for a state committed to social equity, as well as formal equality. State activities are pivotal in defining citizenship.

\section{Focusing on the state at all levels}

The state-focus of disability activism in Canada goes back to the early twentieth century and is an outstanding characteristic of contemporary activism. As the mass media and social sciences express general concerns about declining civic engagement in democracies, disabled people are striving to increase their voices and involvement in public affairs. The Canadian disability movement has a conception of the political that includes not just governments, legislatures, and courts but also families and social networks, the voluntary sector, the economy, and cultural practices. The disability movement engages extensively with government bureaucracies, cabinet ministers, 
parliamentary committees, courts and tribunals, and political parties and elections.

Conventional mainstream political activities are the route taken to mainstream disability concerns. Largely adopting a reformist view of politics, there is a commitment to pursuing societal change through democratic dialogue, where available, and to research on issues, and public awareness and education. The disability movement has some faith in the efficacy of public action for alleviating poverty, tackling inequalities, and promoting accessibility. Disability groups present issues to Canadian decision makers in terms of unfair obstacles, blocked access, unmet needs, and inadequate social inclusion; they engage in a liberal discourse of equality of opportunity and humanitarianism, compared to a more critical discourse of social oppression and economic exploitation.

Critics point out that policies motivated by social liberalism are surface actions rather than systemic transformations; that this reformist approach fails to tackle the deep structures in the economy and society that are disabling, structures that generate and reproduce divisions of advantages and disadvantages. That said, "Citizenship rights are not simply empty civil rights which are utilized to reinforce existing inequalities" (Turner 1986: 136). As the mainstream constellation of values of Canadians, social liberalism does generate critiques of capitalist relationships and sets some limits on market practices. It is how most people make sense of their lives and the larger world. In other words, social liberalism is experientially close to the prevailing political culture of the general population and the political opportunity structures for change. As social liberalism, the political ideas of disability activism see a positive function for the state. There are active roles for the federal, provincial, and municipal governments in showing 
leadership, tackling obstacles, providing essential services and supports, and ensuring sustained efforts on reforms. Depending on program design and actual delivery, public services can have positive effects in alleviating social exclusion and improving economic security.

Some Canadian observers characterize as positive the relations between disability groups and government organizations, with the two sectors performing different yet complementary roles in policy development and implementation. They draw attention to "the mutuality of relationships between the "official" roles of government and the "unofficial" roles of disability organizations" (Enns and Neufeldt 2003: 4). There are two problematic aspects to this statement. One is that the terms official and unofficial create a hierarchy of legitimacy between state and civil sectors, and undermines notions of public accountability by governments to citizens. Second, as disability activists and academics point out, roles between government and the community are not always complementary and certainly not symmetrical in terms of power resources (Chouinard and Crooks, 2008). A naïve emphasis on "the mutuality of relationships" can result in the imposition of official agendas, co-opting disability groups into uneven policy processes.

As socio-political critique, liberalism has long aimed at "freeing the individual from the outdated restraints of old fashioned institutions" (Macpherson 1977: 21). In this regard, disability groups are involved in challenging old beliefs and practices about the limits of impairments, the supposed unemployable status of many people with disabilities, and the assumed benefits of specialized institutions for persons with 
intellectual disabilities. Part of the cultural politics of this social movement involves disability groups and others challenging the paternalistic views that persons with disabilities are defective, helpless, dependent, and needy users of services, and instead, offering positive images of persons with disabilities as individuals with capacities, capable of diverse forms of self-development and social contributions, and as citizens entitled to the same expectations and opportunities, freedoms, rights, and responsibilities as other Canadians.

The community living movement continues to call for the closure of institutions in a number of Canadian jurisdictions that segregate people labelled as having an intellectual disability and as strictly limited in their ability to exercise control over their lives. Many within the movement are skeptical of the continued reliance on a charitable model for meeting needs and the worthy poor approach to disability issues (Hutchison et al. 2007; Rioux and Prince 2002). They regard notions of charity and deserving poor as outdated perspectives that propagate a view of disability as an individual pathology, along with separate, disparate benefits and services that weaken both self-dignities and social cohesion.

\section{Connecting, Colliding and Continuing Liberalisms}

The political project of enabling citizenship for all persons with disabilities therefore requires disrupting the benign aura of neo-liberalism. The disability movement in Canada offers a form of social liberalism with a relatively broader and deeper vision of citizenship, one that calls for a renewed role for governments in tackling discriminatory 
values, extending core services and income benefits, and engaging with community groups in governance and policy matters.

Clearly, the disability community operates in a wider ideological context of Canadian society and political economy. As a broad collection of beliefs, liberalism contains different branches with different adherents and, in recent decades in many nations, neo-liberalism is the dominant perspective influencing the conduct of politics and policy (Bakker and Scott 1997; Orsini and Smith 2007; Rice and Prince 2012; Touraine 2001).

Core features of neo-liberalism are in tension with social liberalism. As a belief system, neo-liberalism accepts some forms of government action, yet seriously questions much of what contemporary welfare states do. With respect to citizenship, emphasis is on civil and political liberties and duties; much less priority is on cultural, economic, and social rights. Neo-liberalism is skeptical about the efficiency, effectiveness, and basic necessity for many social services. Such programs and income benefits neo-liberals view as infringing on personal freedom, weakening self-reliance, and thus creating dependency. Championed by certain think tanks, economic interests, and political parties, neo-liberalism aggressively calls for retrenching the state and expanding responsibilities for social provision among the market economy, local community and family. ${ }^{2}$ This translates into demands for less government, fewer laws and entitlements, lower taxes, smaller public services. Coupled with this is a deep-seated preference for market solutions for many social problems and human needs, complemented with greater 
responsibility by individuals and families with assistance from charitable and voluntary groups.

At times, the two liberalisms intersect in what seem to be mutual messages, though usually for different motives. Neo-liberal criticisms of public bureaucracies and of professionally dominated health and social services echo claims by disability advocacy groups for more responsive service delivery, self-determination and direct payments, and a greater voice in policy making and program evaluations (McColl and Jongbloed 2006).

Neo-liberalism is a significant factor in contemporary Canadian politics. Relatively few Canadians interpret disability as an economic issue of employment or as a matter of human rights. Neo-liberal thinking is apparent in opinion survey findings that far more Canadians prefer to tackle discrimination, exclusion, and stigma of persons with disabilities through information campaigns than through public programs, legislation, and income benefits. This is a preference for what we might call a "soft" politics of recognition over a "substantive" politics of redistribution. Through its activism, therefore, the Canadian disability community presses against ableist beliefs and practices, as well as neo-liberal beliefs and practices, each with implications for shaping conceptions of citizenship, policy, and politics. In recent times, on most issues, it seems neo-liberalism has the upper hand in power and governance in modern societies.

In Canadian social policies and practices, neo-liberal ideas have made inroads. Rioux and Valentine (2006), for example, argue that the dominance of neo-liberalism has 
resulted in a conceptual and practical restructuring of disability, equality, and citizenship. They suggest that in many public programs the idea of disability has slid back into a notion of individual pathology; the notion of equality replaced by that of fair opportunity rather than a right to equal treatment or outcomes; and talk of citizenship gives greater emphasis to domestic responsibilities and charitable giving. In a study on home support policies and services for people with disabilities, Krogh and Johnson (2006) found that neo-liberalism, in the form cost-cutting measures, meant "fewer people being eligible for services, a reduction in the type of services available and wider implementation of user fees." The result was reduced expectations among people with disabilities for home supports, wider variations in services across provincial jurisdictions, and "reduced life opportunities and options for people who rely on the service" (Krogh and Johnson 2006: $153)$.

We should not over generalize the depth or extent of these ideological and material encroachments. Neo-liberalism has not totally triumphed over social rights and citizenship in Canada (Armitage 2003; Bashevkin 2002; Boychuk 1998). Across policy areas, client groups, and jurisdictions impacts are variable. Emphatically, there is unmistakable contraction to major social programs such as unemployment insurance (Campeau 2004), greater stress on employability of income assistance recipients (Little and Marks 2006), and successive tax cuts. Over the same period, however, witness popular resistance to the privatization of public services, most notably health care, and the debate over extending coverage for palliative care and drug insurance, among other issues. Eligibility has expanded to some income programs and tax measures, and a 
number of new financial benefits appeared in recent years, including a universal benefit for all young children in Canada.

Social liberalism and neo-liberalism overlap in certain key respects. Both speak of the importance of individual rights, personal choices, and self-care, along with accountability as a positive organizational practice. Both subscribe to the central importance of material wellbeing and both, to a degree, contain critiques of professional power and therapeutic knowledge. Notable differences in these two forms of liberal beliefs are over the scope of citizenship as a bundle of rights and duties (Baker 2008), on the validity of group identities in social policy and democratic politics, and on their respective interpretation of the meaning of entitlements and obligations.

In these ways, social liberalism and neo-liberalism are distinctive yet also closely interlinked projects for constructing community membership and civic participation. Being indiscrete systems of ideas, neo-liberalism and social liberalism overlap, clash, and develop together. They will continue shaping both the context of Canadian politics and the content of public policies.

\section{Conclusion}

This article offers an exploration into the liberal democratic thinking of the disability movement in Canada. My aim has been to examine the ideas and claims of the disability community as a political movement and to compare and contrast those ideas to the 
prevailing political ideas in Canadian politics. The discussion shows that the disability movement inevitably operates in the company of dominant political ideas and social beliefs. From a values perspective, strategies by disability groups, self-advocates and associations involve implicitly or explicitly accepting most values; but, also, questioning certain assumptions and popular beliefs; and, pointing out the failure of social groups, economic markets and business firms, and political organizations to uphold core principles and commitments contained in community practices or in federal or provincial legislation and public policies.

In relation to other studies on social movements and social policy in Canada, the disability movement combines elements of what Carroll and Ratner (1996) call identity politics and a liberal injustice frame; what Mahon (2008) calls the varieties of liberalism, namely, neo-, social, and inclusive liberalism; or what Rice and Prince (2012) call the policy orientations of economic liberalism, social protection and cultural recognition. Thus, the political awareness of the disability movement tends to resist many elements of the contemporary turn to neo-liberalism, as well as longstanding beliefs and practices from the so-called golden years of the welfare state, expressing a social vision of a more accessible, caring, just and inclusive society, pursued through policy advocacy, rights claims and community change.

Like other social movements in Canada, and undoubtedly in other countries too, the disability movement's approach to social change, policy making and advancing full citizenship is a reformist approach. The disability movement is arguing for policy 
developments and changes within existing structures of the labour market, education systems, government institutions, and community agencies. In some aspects, the Canadian disability movement's style of activism resembles elements of progressive social administration and social democratic thought. Canada's disability movement exhibits strong faith in both empiricism and idealism: a durable belief in the role of research and information on lived experiences in raising public awareness and shifting support for change; and, a deep commitment to the power of ethical ideas and moral claims in advancing the status of persons with disabilities. Moreover, the movement has a structural and materialist dimension to its analysis of exclusion and marginalization, pointing out the economic, cultural and systemic barriers facing disabled people. For the most part, these structural and material claims are embedded in a larger liberalism that pervades both the movement and the country's political culture.

The Canadian disability movement's main political outlook is a brand of social liberalism. It is liberal because the movement champions the autonomy and selfdevelopment of individuals, values of toleration and respect, and takes for granted market relations, the rule of law, and representative democratic government. It is social because the movement celebrates groups and group rights, while emphasizing the importance of active government. The movement works with the state, addressing issues of material needs of distribution (income, employment, housing, transit, and so on), cultural recognition (public attitudes, social values and beliefs), and democratic voice (constitutional, electoral, and legislative protections). Most of the disability movement's activism is squarely within conventional political practices and governmental structures, 
such as parliamentary committees, advisory councils, and election campaigns. As a form of social liberalism, disability activism is a wavering mixture of criticism and collaboration with governments, and of visionary ideals and incremental reforms. As earlier noted, the social liberalism of disability politics often clashes with the neoliberalism of state retrenchment, charity, and privatization. Yet, in this ideological nexus, opportunities arise for at least some disabled people and disability groups, to advance greater self-control and acquire community resources. Such opportunities include recent income assistance reforms in Saskatchewan for people with significant disability; accessibility legislation for Ontarians with disabilities; the registered disability savings plan, nationally, for those with the financial means at hand; and, poverty reduction strategies in certain provinces, such as Quebec and Newfoundland and Labrador, with targeted measures for people with disability.

Voicing claims for essential services and basic income support in the language of citizenship is central to Canadian disability politics, and reveals social liberalism as the major ideological thread of this community. A discourse of citizenship seeks to legitimate claims using a familiar set of concepts around equality and opportunity, and to connect with the wider political community on aspirations of belonging and participation. Canadian disability politics is eroding old notions of the disabled as defective, sick, tragic figures lurking in the margins of communities. Through various kinds of engagement, disability groups are representing people with disabilities in two senses of the word: speaking on behalf of their membership, and depicting people with disabilities as persons 
with innate dignity and worth, as social actors with identities, capabilities rights and responsibilities.

The complex internal nature of neo-liberalism itself plus the presence of alternative structures of beliefs, interacting in countless ways, presents neo-liberalism as less predictable, stable or omnipotent as sometimes claimed. The interplay between neoliberalism and social liberalism, and resultant effects for political activism and agenda setting, continue to shape policy making and social citizenship for persons with disabilities and other marginalized groups in society. To talk of a new historical period in social policy, post-neo-liberalism (Touraine 2001; Perkins, Nelms and Smyth 2004), may seem empirically premature or overly optimistic; more significantly, it thinks of the development of nation states and societies in terms of epochal shifts and master narratives. An alternative analytical approach is to 'treat 'post-welfarism' as designating a field of still contested attempts to 'map' and govern the social in new ways. The transformation of welfare capitalism is a continuing, rather than a completed, process, not least because of the potency of residual and emergent conceptions of the social that resist the attempts to subordinate it to the economic in new ways" (Clarke 2007: 980). These interplays recommend the importance of further studying the existing range of political ideas, collective movements, and welfare state reforms for both the purpose of scrutinizing neo-liberalism from other vantage points and of exploring processes of formulating the social. 
In Canadian disability studies the 'social model of disability' includes a family of related notions which includes socio-political, cultural, environmental, human rights, and equality conceptions of disablement (Cameron and Valentine 2001; Enns and Neufeldt 2003; McColl and Jongbloed 2006; Pothier and Devlin 2006; Stienstra and Wight-Felske 2003; Titchkosky 2003). Each of these concepts goes beyond biological, medical and charitable understandings of disability to express a set of ideas and beliefs that emphasize the fundamental importance of systemic barriers, social structures of opportunities and political choices. Along with an obvious emphasis on collectivist values, these social understandings of disability underline the significance of certain individualist values, which are apparent in social liberalism. Social models of disability do not deny totally the place of individuality in analysis or in activism. What social models do reject is a narrow perspective on individualism, one which views a person as a particular market actor or as a private person, with specific rights and duties derived from the self and disassociated from other people (Macpherson 1977; Myles 1998; Rioux and Valentine 2006). Critical perspectives on disability tend to express a liberal individualism in at least two respects: one is that each person is a moral whole with equal ethical worth; and, the second is a belief in the value of community and that the individual is part of a larger social whole, a common humanity. These beliefs contain the ideas of inherent dignity and expected interdependence as well as that self-determination and justice depend on consent, forgiveness, healing, inclusion and participation in communities (Prince 2009; Vanier 1998). 
Social liberalism, then, is a cultural and political milieu filled with actual and would-be possibilities and challenges for bridging experiences of impairments and disablements across many intersections of differences within our federal political communities.

\section{Notes}

${ }^{1}$ In recording direct observations, interpreting information, and formulating the analysis developed in this article, I am grateful for the ongoing engagement with, and insightful suggestions of activists, allies and leaders in several organizations within the Canadian disability movement. Primarily, this article focuses on neo-liberalism and social liberalism as structures of beliefs and ideas, and, secondly, as technologies and practices of governing. Beyond the scope of this article is the issue of what the interplay of neoliberalism and social liberalism (and other ideological perspectives for that matter) mean for state formation and overall governance. A diverse and modest body of literature examines the interplay of neo-liberalism and social liberalism. See, for instance, Soederberg's analysis of the national solidarity program in Mexico (Soederberg 2001); the discussion by Higgins and Lockie (2001) on social and neo-liberal hybrid practices in rural natural resource management in Australia; and, on social policy and the welfare state, see Clarke (2007), Perkins, Nelms and Smyth (2004), Prince (2001), and Rice and Prince (2012).

${ }^{2}$ Little and Marks (2006) offer a detailed analysis of neo-liberal reforms to welfare policies in these two large jurisdictions of Canada. They note there are differences in the 
interpretation and implementation of neo-liberalism by governments in their relative emphasis on fiscal and or social values and in their choice of policy tools to effect a transformation of the welfare state. 


\section{References}

Anspach, R.R. (1979) From stigma to identity politics: Political activism among the physically disabled and former mental patients. Social Science and Medicine 13A:76573.

Armitage, A. (2003) Social Welfare in Canada. (4th ed.), Toronto: Oxford University Press.

Aronson, J., and S.M. Neysmith. (2001) Manufacturing social exclusion in the home care market. Canadian Public Policy 27, 2: 151-65.

Baker, D.L. (2008) Issue definition in rights-based policy focused on the experiences of individuals with disabilities: an examination of Canadian parliamentary discourse.

Disability \& Society, 23, 6: 571-83.

Bakker, I., and K. Scott. (1997) From the Postwar to the Post- Liberal Keynesian Welfare

State. In W. Clement, (ed.) Understanding Canada: Building on the New Canadian

Political Economy, Montreal and Kingston: McGill-Queen's University Press, pp. 286310.

Bashevkin, S. (2002) Welfare Hot Buttons: Women, Work and Social Policy Reform, Toronto: University of Toronto Press.

BCCPD (2011) Woodlands Campaign, Vancouver: BC Coalition of People with Disabilities, http://www.bccpd.bc.ca/campaigns/woodlands/default.htm Boychuk, G.W. (1998) Patchworks of Purpose: The Development of Provincial Social Assistance Regimes in Canada, Montreal and Kingston: McGill- Queen’s University Press. 
Burstow, B. and D. Weitz (eds), (1988) Shrink Resistant: The struggle against psychiatry in Canada, Vancouver: New Star Books.

Cameron, D. and F. Valentine. (2001) Comparing policy-making in federal systems: The case of disability policy and programs - an introduction. In D. Cameron and F. Valentine, (eds), Disability and Federalism: Comparing Different Approaches to Full Participation, Montreal and Kingston: McGill-Queen's University Press, pp. 1-44.

Campeau, G. (2004) From UI to EI: Waging War on the Welfare State, (Trans. by R.

Howard). Vancouver: University of British Columbia Press.

Capponi, P. (1992) Upstairs in the Crazy House: The Life of a Psychiatric Survivor, Toronto: Viking.

Carroll, W.K. and R.S. Ratner (1996) Master Frames and Counter-Hegemony: Political Sensibilities and Contemporary Social Movements, Canadian Review of Sociology and Anthropology, 33, 4: 407-35.

Chivers, S. (2008) Barrier by barrier: The Canadian disability movement and the fight for equal eights.' In M. Smith, (ed), Group Politics and Social Movements in Canada, Peterborough, ON: Broadview Press, pp. 307-28.

Chouinard, V. and V.A. Crooks (2008) Negotiating neoliberal environments in British Columbia and Ontario, Canada: restructuring of state-voluntary sector relations and disability organizations' struggle to survive, Environment and Planning C: Government and Policy, 26: 173-90.

Clarke, J. (2007) Subordinating the social? Neo-liberalism and the remaking of welfare capitalism, Cultural Studies, 21, 6: 974-87. 
Clawson, D. (2008) Neo-Liberalism guarantees social movement unionism, Employee Responsibilities and Rights Journal, 20, 3: 207-12.

Delanty, G. (2000) Citizenship in a global age: society, culture and politics, Buckingham: Open University Press.

Devlin, R. and D. Pothier. (2006) Introduction: Toward a critical theory of discitizenship.' In D. Pothier and R. Devlin, (eds), Critical Disability Theory: Essays in Philosophy, Politics, Policy, and Law, Vancouver: University of British Columbia Press, pp. 1-22.

Dwyer, P. (2004) Understanding Social Citizenship, Bristol: Policy Press.

Enns, H. and A.H. Neufeldt, (eds), (2003) In Pursuit of Participation: Canada and Disability at Home and Abroad, Concord, ON: Captus Press.

Guest, D. (2003) The Emergence of Social Security in Canada (3rd ed.), Vancouver: University of British Columbia Press.

Higgins, V. and S. Lockie (2002) Re-discovering the social: neo-liberalism and hybrid practices of governing in rural natural resource management, Journal of Rural Studies, 18, 4: 419-28.

Hutchison, P., S. Arai, A. Pedlar, J. Lord, and F. Yuen. (2007) Role of Canadian user-led disability organizations in the nonprofit sector. Disability and Society 22, 7: 701-16.

Krogh, K. and J. Johnson. (2006) A Life without Living: Challenging Medical and Economic Reductionism in Home Support Policy for People with Disabilities. In D. Pothier and R. Devlin, (eds), Critical Disability Theory: Essays in Philosophy, Politics, Policy, and Law, Vancouver: University of British Columbia Press, pp. 151-76. Lister, R. (1997) Citizenship: Feminist Perspectives, London: Macmillan. 
Little, M. and L. Marks (2006) A closer look at the neo-liberal Petri dish: Welfare reform in British Columbia and Ontario, Canadian Review of Social Policy, No. 57: 16-45.

Lorinc, J. (2006) The New City: How the Crisis of Canada's Urban Centres is Reshaping the Nation, Toronto: Penguin Canada.

Macpherson, C.B. (1977) The Life and Times of Liberal Democracy, Oxford: Oxford University Press.

Mahon, R. (2008) Varieties of liberalism: Canadian social policy from the Golden Age to the present. Social Policy \& Administration, 42, 4: 342-61.

McBride, S., and K. McNutt (2007) Devolution and Neoliberalism in the Canadian Welfare State. Global Social Policy, 7, 2: 177-201.

McColl, M.A., and L. Jongbloed, (eds), (2006) Disability and Social Policy in Canada (2nd ed), Concord, ON: Captus University Press.

McDaniel, S.A. (2002) Women's changing relations to the state and citizenship: Caring and intergenerational relations in globalizing western democracies. Canadian Review of Sociology and Anthropology, 39:125-50.

Michalko, R. (2002) The Difference that Disability Makes, Philadelphia: Temple University Press.

Myles, J. (1998) How to Design a "Liberal" Welfare State: A Comparison of Canada and the United States. Social Policy and Administration, 32, 4: 341-64.

O’Connor, J., A. S. Orloff, and S. Shaver (1999) States, Markets, Families: Gender, Liberalism and Social Policy in Australia, Canada, Great Britain and the United States, Cambridge: Cambridge University Press. 
Orsini, M., and M. Smith, (eds), (2007) Critical Policy Studies, Vancouver: University of British Columbia Press.

Perkins, D., L. Nelms, and P. Smyth (2004) Beyond neo-liberalism: The social investment state? Social Policy Working Paper No. 3, Centre for Public Policy, University of Melbourne.

Prentice, S. (2004) Manitoba's Childcare Regime: Social Liberalism in Flux, Canadian Journal of Sociology, 29, 2:193-207.

Prince, M.J. (2001) How social is social policy? Fiscal and market discourse in North America welfare states, Social Policy \& Administration, 35, 1: 2-13.

Prince, M.J. (2009) Absent Citizens: Disability Politics and Policy in Canada, Toronto: University of Toronto Press.

Rice, J.J., and M.J. Prince. (2012) Changing Politics of Canadian Social Policy, $\left(2^{\text {nd }}\right.$ ed), Toronto: University of Toronto Press.

Rioux, M.H., and M.J. Prince. (2002) The Canadian political landscape of disability:

Policy perspectives, social status, interest groups and the rights movement.' In A. Puttee, (ed), Federalism, Democracy and Disability Policy in Canada, Montreal and Kingston: McGill-Queen's University Press, pp. 11-28.

Rioux, M.H., and F. Valentine. (2006) Does theory matter? Exploring the nexus between disability, human rights, and public policy. In D. Pothier and R. Devlin, (eds), Critical Disability Theory: Essays in Philosophy, Politics, Policy, and Law, Vancouver:

University of British Columbia Press, pp. 47-69.

Schaefer, R.T., and E. Smith. (2005) Sociology: First Canadian Edition, New York: McGraw-Hill Ryerson. Canadienne des Études sur l'Incapacité and is Hosted and Supported by the University of Waterloo 
Shimrat, I. (1997) Call me crazy: stories from the mad movement, Vancouver: Press gang.

Soederberg, S. (2001) From neoliberalism to social liberalism: Situating the National Solidarity Program within Mexico’s Passive Revolution, Latin American Perspectives. 28, 3: 104-23.

Stienstra, D., and A. Wight-Felske, (eds), (2003) Making Equality: History of Advocacy and Persons with Disabilities in Canada, Concord, ON: Captus Press.

Titchkosky, T. (2003) Disability, Self, and Society, Toronto: University of Toronto Press.

Touraine, A. (2001) Beyond Neoliberalism, Cambridge: Polity.

Turner, B.S. (1986) Citizenship and Capitalism: The Debate over Reformism, London:

Allen \& Unwin.

Vanier, J. (1998) Becoming Human, Toronto: House of Anansi Press. 